\title{
Hepatic and serum folates in patients fasting and after oral folic acid
}

\author{
D. W. DAWSON AND C. GEARY' \\ From the Department of Pathology, Crumpsall Hospital, Manchester
}

SYNOPSIS The hepatic folate in non-anaemic hospital patients was found to correlate poorly with the fasting serum folate. The rise in methylfolate in the systemic circulation following the absorption of folic acid was directly related to the folate content of the liver.

The serum folate is sensitive to minor changes in folate intake and requirement and is thus of limited value as an index of folate status. The liver is the main site of the stores of this vitamin in man. Waters (1963) recorded excellent correlation between the serum and liver folates in megaloblastic anaemias and in a few control patients. Chanarin, Hutchinson, McLean, and Moule (1966) apparently confirmed this relationship in a series of hospital patients, but their results are actually not significant. We have therefore compared the serum and hepatic folates in a similar group of patients.

When folic acid is ingested a portion is reduced and methylated in the gut wall (Chanarin and Perry, 1969) but the remainder passes to the liver where it exchanges with stored methylfolate (Chanarin, 1969). Any subsequent rise in systemic blood folate is due to unaltered folic acid, to methylated absorbed folic acid, and to displaced methylfolate. Tests have been carried out to compare the increment in serum methylfolate after ingestion of folic acid with the hepatic folate.

\section{Material and Methods}

\section{MATERIAL}

Twenty-five patients undergoing either cholecystectomy or pyloroplasty and vagotomy gave permission, after the purpose of the investigation had been explained to them, for the surgeon to take a liver biopsy at the time of the operation. Blood for serum folate was taken, and a folate absorption test $(40 \mu \mathrm{g} /$ $\mathrm{kg}$ body weight folic acid, Folvite, given in water to the fasting patient without prior saturation with folic acid) was carried out during the first week after Received for publication 14 July 1970.

'Present address: The Royal Infirmary, Manchester. operation. A second sample of blood was taken two hours later for the postabsorption serum folate assay. None of the patients was anaemic or had evidence of malabsorption or liver disease.

\section{ASSAYS}

The liver samples were prepared for assay by the method of Chanarin et al (1966). These and the serum folate were assayed using $L$. casei (ATCC 7469) and the postabsorption serum using $L$. case $i$ and Str. faecalis (NCIB 6459). The fasting serum level has been deducted from the $L$. casei postabsorption level recorded. In our laboratory the normal serum folate is $3-8 \mathrm{ng} / \mathrm{ml}$.

\section{Results}

The assay results are listed in the Table. The folate content of the liver samples ranged from 0.8 to $23.0 \mu \mathrm{g} / \mathrm{g}$ with a mean of $7 \cdot 1 \mu \mathrm{g} / \mathrm{g}$.

Ten of the 15 patients with a liver folate content of $5 \mu \mathrm{g} / \mathrm{g}$ or more had a normal serum folate, and 10 of the 13 with a normal serum folate had a liver folate of $5 \mu \mathrm{g} / \mathrm{g}$ or more. However, the coefficient of correlation ( $r$ ) for all the results is not significant at $\mathbf{0 . 2 3}$.

There was significant correlation between the hepatic folate $(x)$ and the difference between the two-hour postabsorption serum assays $(y)$ (column $5 ; \mathrm{r}=0.57 ; 0.001<\mathrm{P}<0.01)$. The regression lines $y=1.9 x+3.9$ and $x=0.2 y+2.0$ could be fitted to the graphed points.

There was less, but still significant, correlation between the hepatic folate and the rise in total serum folate, as assayed by $L$. casei (column $3 ; \mathrm{r}=0.42$; $0.01<P<0.05$ ).

The fasting serum folate also correlated well with the rise in total serum folate $(\mathrm{r}=0.50 ; 0.01<\mathrm{P}<$ $0.05)$. 


\begin{tabular}{|c|c|c|c|c|c|}
\hline \multirow[t]{2}{*}{ Case } & \multirow{2}{*}{$\begin{array}{l}\begin{array}{l}\text { Liver } \\
(\mu g / g)\end{array} \\
1\end{array}$} & \multirow{2}{*}{$\begin{array}{l}\begin{array}{l}\text { Serum } \\
(n g / m l)\end{array} \\
2\end{array}$} & \multicolumn{3}{|c|}{ Postabsorption Serum $(\mathrm{ng} / \mathrm{ml})$} \\
\hline & & & $\begin{array}{l}\text { L. Casei } \\
3\end{array}$ & ${ }_{4}^{\text {Str. faecalis }}$ & $\begin{array}{l}3-4 \\
5\end{array}$ \\
\hline 1 & $2 \cdot 5$ & $2 \cdot 1$ & 91 & 56 & 35 \\
\hline 2 & $10 \cdot 0$ & $6 \cdot 2$ & 105 & 70 & 35 \\
\hline 3 & $6 \cdot 5$ & $1 \cdot \overline{5}$ & 13 & 0 & 13 \\
\hline 4 & $4 \cdot 3$ & $1 \cdot 3$ & 9 & 8 & 1 \\
\hline 5 & $2 \cdot 8$ & 1.9 & 79 & 80 & 0 \\
\hline 6 & 0.8 & 2.9 & 50 & 53 & 0 \\
\hline 7 & $5 \cdot 9$ & 3.0 & 29 & 25 & 4 \\
\hline 8 & $7 \cdot 5$ & $3 \cdot 4$ & 81 & 39 & 42 \\
\hline 9 & $2 \cdot 5$ & 3.0 & 60 & 40 & 20 \\
\hline 10 & 15.0 & 1.5 & 69 & 43 & 26 \\
\hline 11 & $12 \cdot 5$ & 5.0 & 102 & 71 & 31 \\
\hline 12 & $6 \cdot 2$ & 5.0 & 78 & 80 & 0 \\
\hline 13 & $4 \cdot 5$ & $2 \cdot 1$ & 13 & 1 & 12 \\
\hline 14 & $8 \cdot 3$ & $6 \cdot 8$ & 21 & 18 & 3 \\
\hline 15 & $5 \cdot 2$ & $2 \cdot 0$ & 13 & 0 & 13 \\
\hline 16 & $12 \cdot 5$ & $6 \cdot 3$ & 72 & 46 & 26 \\
\hline 17 & $5 \cdot 0$ & $2 \cdot 3$ & 15 & 16 & 0 \\
\hline 18 & $7 \cdot 5$ & $3 \cdot 2$ & 31 & 10 & 21 \\
\hline 19 & 15.0 & 4.0 & 60 & 25 & 35 \\
\hline 20 & 2.9 & 1.9 & 26 & 18 & 8 \\
\hline 21 & $3 \cdot 4$ & 5.0 & 95 & 100 & 0 \\
\hline 22 & $3 \cdot 4$ & 3.9 & 90 & 92 & 0 \\
\hline 23 & $6 \cdot 3$ & 6.0 & 150 & 93 & 57 \\
\hline 24 & $2 \cdot 8$ & $2 \cdot 7$ & 40 & 33 & 7 \\
\hline 25 & 23.0 & $2 \cdot 8$ & 148 & 104 & 44 \\
\hline Mean & $7 \cdot 1$ & $3 \cdot 4$ & 61 & 45 & 17 \\
\hline
\end{tabular}

Table Folate assays in liver and blood specimens ${ }^{1}$

'Figures in column 5 are the difference between the postabsorption L. case $i$ and Str. faecalis assays.

\section{Discussion}

The range of liver folates in the patients investigated here is similar to that obtained by Chanarin et al (1966). Although there appears to be some relationship to the fasting serum folate in the majority of the patients, the finding of a high liver folate in the presence of a low serum folate in a few renders the results statistically not significant, a conclusion also applicable to the findings in the surgical patients of Chanarin et al (1966). Analysis of their results yields an insignificant value for $\mathrm{r}$ of 0.04 . The excellent correlation between liver and serum folates obtained by Waters (1963) occurred in patients with megaloblastic anaemias due to either folate deficiency or to vitamin $B_{12}$ deficiency associated with a relatively high serum folate. Leevy, Cardi, Frank, Gellene, and Baker (1965) also noted a fall in both the serum and hepatic folates in patients with folate deficiency and macrocytic anaemia. But such changes are compatible with our finding of lack of correlation in lesser degrees of folate deficiency, which may be attributable to the serum folate being more suscep tible and responsive to alterations in intake, demand or loss.

After an oral dose of folic acid there is a rise in the systemic blood folate. That to which Str. faecalis is sensitive is usually maximal within one to two hours, that assayable by $L$. casei at four hours (Baker Frank, Feingold, Ziffer, Gellene, Leevy, ando Sobotka, 1965). The former at any one time repres sents mainly the folic acid absorbed but not taker $P$ up by the liver. The rise in the $L$. casei-sensitive material is in addition due to methylfolate released from the liver and folate methylated in the gut wallo The relationship between the liver and methylfolate increment in this series indicates that, when the patient is presented with a dose of folic acid of the order used here, the degree of methylation in the gut wall is not appreciable. Whitehead and Coopero (1967) did not detect intestinal methylation of folic acid when they used doses of the order of $1 \mathrm{mg}$.

Measurement of the hepatic folate is the "final court of appeal' in the diagnosis of folate deficiency (Chanarin, 1968). But a liver biopsy may not bछ obtainable in patients in whom serum and erythro-cyte assays yield equivocal results. Our investigations show that an indirect assessment of the hepatio content may be made by the estimation of methyl folate displaced from the liver by an oral dose op folic acid, providing that its absorption is normal.

We wish to thank Mr H. M. Goldberg and Mr R. C $\overrightarrow{0}$ Hartley for providing us with liver biopsy samples?

References

Baker, H., Frank, O., Feingold, S., Ziffer, H., Gellene, R. A., Leevy C. M., and Sobotka, H. (1965). The fate of orally and parentero ally administered folates. Amer. J. clin. Nutr., 17, 88-95.

Chanarin, I. (1968). The diagnosis of folate deficiency. In Receni Advances in Clinical Pathology, Series V, edited by S. C. DykeO p. 201. Churchill, London.

Chanarin, I. (1969). The Megaloblastic Anaemias, p. 295. Blackwell Oxford.

Chanarin, I., Hutchinson, M., McLean, A., and Moule, M. (1966) Hepatic folate in man. Brit. med. J., 1, 396-399.

Chanarin, I., and Perry, J. (1969). Evidence for reduction and methyla tion of folate in the intestine during normal absorptionn Lancet, 2, 776-778.

Leevy, C. M. Cardi, L.,Frank, O., Gellene, R, and Baker, H. (1965) Incidence and significance of hypovitaminemia in a randomlo selected municipal hospital population. Amer. J. clin. Nutr. NJ $17,259-271$.

Waters, A. H. (1963). Folic Acid Metabolism in the Megaloblast Anaemias. PhD Thesis, London.

Whitehead, V. M., and Cooper, B. A. (1967). Absorption of unaltere folic acid from the gastro-intestinal tract in man. Brit. Haemat., 13, 679-686. 